\title{
Annie Mavrakis, «Un rêve de Michel Butor»
}

\section{Elisa Bricco}

\section{(2) OpenEdition}

\section{Journals}

\section{Edizione digitale}

URL: http://journals.openedition.org/studifrancesi/35243

DOI: 10.4000/studifrancesi.35243

ISSN: 2421-5856

\section{Editore}

Rosenberg \& Sellier

\section{Edizione cartacea}

Data di pubblicazione: 1 novembre 2005

Paginazione: 453

ISSN: 0039-2944

\section{Notizia bibliografica digitale}

Elisa Bricco, «Annie Mavrakis, «Un rêve de Michel Butor»», Studi Francesi [Online], 146 (XLIX | II) | 2005, online dal 30 novembre 2015, consultato il 19 avril 2021. URL: http://journals.openedition.org/ studifrancesi/35243 ; DOI: https://doi.org/10.4000/studifrancesi.35243

Questo documento è stato generato automaticamente il 19 avril 2021.

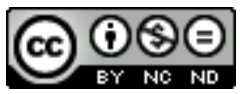

Studi Francesi è distribuita con Licenza Creative Commons Attribuzione - Non commerciale - Non opere derivate 4.0 Internazionale. 


\title{
Annie Mavrakis, «Un rêve de Michel Butor»
}

\author{
Elisa Bricco
}

\section{NOTIZIA}

ANNIE MAVRAKIS, «Un rêve de Michel Butor», Poétique, 139, sept. 2004, pp. 315-323.

1 La riflessione sul rapporto tra pittura e letteratura ha sempre appassionato gli scrittori che si sono cimentati con l'ekphrasis, o che si sono interrogati sui possibili legami tra le diverse forme di creazione. Il presente saggio indaga sulla relazione tra pittura e scrittura letteraria in un testo di Michel Butor: Le Rêve de Paul Delvaux, apparso nel catalogo delle opere del pittore, nel 1975. L'autore dimostra come in questo testo le due forme artistiche sono intimamente legate, non tanto perché la scrittura descrive la pittura, ma poiché la pittura suggestiona la scrittura e funge da motore finzionale. Infatti, nel testo, Butor parte da un'iniziale descrizione del lavoro di Delvaux per proseguire poi liberamente verso la messa in scena di un universo finzionale nel quale i personaggi, evocati da lui a partire dall'osservazione, prendono vita, e l'universo pittorico prende vita all'interno del testo stesso. Questo universo finzional-pittoricoonirico è animato e anche permeato dalla presenza dello scrittore, quasi lui entri a far parte dell'opera del pittore animandola con le proprie visioni e suggestioni, che appunto da lui hanno preso spunto. Uno stretto rapporto s'instaura dunque tra scrittura e pittura, quest'ultima vista con déclencheur della parola. 